\title{
CLINICAL AND MOLECULAR STUDIES IN FIVE BRAZILIAN CASES OF FRIEDREICH ATAXIA
}

\author{
IDA V.D. SCHWARTZ*, LAURA B. JARDIM**, ANA C.S. PUGA***, SÉRGIO COCOZZA****, \\ SANDRA LEISTNER ${ }^{\star * * * *}$, LUCIANE C. LIMA******
}

\begin{abstract}
Friedreich ataxia (FRDA), the most common autosomal recessive ataxia, is caused in $94 \%$ of cases by homozygous expansions of an unstable GAA repeat localised in intron 1 of the X25 gene. We have investigated this mutation in five Brazilian patients: four with typical FRDA findings and one patient with atypical manifestations, who was considered to have some other form of cerebellar ataxia with retained reflexes. The GAA expansion was detected in all these patients. The confirmation of FRDA diagnosis in the atypical case may be pointing out, as in other reports, that clinical spectrum of Friedreich's ataxia is broader than previously recognised and includes cases with intact tendon reflexes.
\end{abstract}

KEY WORDS: Friedreich ataxia, cerebellar ataxia, expansion of unstable repeats.

\section{Avaliação clínica e molecular de cinco pacientes brasileiros com ataxia de Friedreich}

RESUMO - A ataxia de Friedreich (FRDA) é a mais frequente das ataxias com herança autossômica recessiva. Em $94 \%$ dos casos, é causada por uma expansão homozigota instável da repetição de trinucleotídeos GAA, localizada no primeiro íntron do gene X25. Esta mutação foi investigada em cinco pacientes brasileiros: quatro com quadro clínico típico de FRDA e um paciente com manifestações atípicas, cujo diagnóstico prévio era o de alguma outra forma de ataxia cerebelar com preservação de reflexos. A investigação foi positiva nos cinco casos. A confirmação do diagnóstico de FRDA no paciente com quadro atípico, assim como em outros casos semelhantes já relatados na literatura, sugere que o espectro de manifestações clínicas da FRDA seja mais amplo do que o classicamente reconhecido, incluindo casos com preservação de reflexos.

PALAVRAS-CHAVE: ataxia de Friedreich, ataxia cerebelar, expansão instável de trinucleotídeos.

Friedreich ataxia (FRDA) (OMIM 229300) ${ }^{1}$ is the most common autosomal recessive ataxia, with an estimate frequency of $1 / 50000-2 / 50000^{2}$. Until recently, the usual criteria for its clinical diagnosis included: onset of cerebellar ataxia at $<20$ years old, absence of lower-limb deep-tendon reflexes, extensor plantar responses, reduction of vibratory sense, cardiomyopathy and a predisposition to diabetes mellitus. These criteria excluded patients with late-onset disease, as well as those with retained reflexes. The latter ones were considered to have distinct diseases, such as "early onset cerebellar ataxia with retained reflexes" (EOCA) (OMIM 212895) $)^{1,3}$.

In 1996, the FRDA gene was cloned ${ }^{4}$. The gene called X25 is located on chromosome 9q13 and encodes a 210 amino-acid protein called frataxin. An unstable trinucleotide (GAA) repeat is

*M.D., Serviço de Genética Médica, Hospital de Clínicas de Porto Alegre (HCPA); **M.D., Departamento de Medicina Interna, Universidade Federal do Rio Grande do Sul; ***M.D., Serviço de Genética Médica, HCPA; ****PhD, Departamento de Biologia Celular e Molecular, Universidade Federico II, Nápoles; *****PhD, Serviço de Genética Médica, HCPA; ******Undergraduate student, Serviço de Genética Médica, HCPA. Aceite: 22outubro-1998.

Dra. Ida V.D. Schwartz - Serviço de Genética Médica, Hospital de Clínicas de Porto Alegre - Rua Ramiro Barcellos 2350 - 90035-003 Porto Alegre RS - Brasil. FAX: 051316 8010. E-mail: ida@ez-poa.com.br 
present in the first intron of this gene. The GAA motif is present from 7 to 22 times in the normal population. In FRDA population, however, it is amplified 200-900 times. This expansion results in a decreased expression of the target frataxin gene, and it is meiotically and mitotically unstable. Further analysis revealed that frataxin is encoded as part of the STM7 gene ${ }^{5}$, and that the repetitive motif is localised in the intron 18 of the STM7 gene, which encodes a catalytic domain of a phosphatidylinositol-4-phosphate-5-kinase. This enzyme has been proposed to be essential for vesicular trafficking or synaptic transmission, but its role on FRDA is still controversial ${ }^{5}$.

Yeasts deficient in frataxin homologue (YFH1) have respiratory incompetence and accumulate iron in mitochondria. On the other hand, iron deposits have been demonstrated in the heart of FRDA patients. Although the actual function of frataxin is not yet clear, these findings suggest that FRDA patients suffer from free radical toxicity causing mitochondrial dysfunction ${ }^{6}$.

The X25 gene cloning brought more strict diagnostic criteria for patients with classical or atypical FRDA manifestations. The purposes of this report are: (1) to present our first patients with molecular diagnosis of FRDA, and (2) to stress the necessary inclusion of atypical clinical pictures under this diagnosis.

\section{METHODS}

We have included five Brazilian patients in this study, four with clinical diagnosis of FRDA and one atypical patient. They all agreed on having the DNA analysis for the X25 gene performed.

Molecular analysis of four patients (Cases 1,2,3 and 5) included in this study were performed in Naples, Italy. The analysis in one of the patients (Case 4) was performed in our laboratory in Brazil. The DNA was extracted from peripheral blood leukocytes using the "salting out" precipitation method by Miller et al. ${ }^{7}$ and amplified by PCR using the ELONGASE ${ }^{\mathrm{TM}}$ Enzyme Mix (GIBCO BRL) according to the manufacturers instructions. The primers and PCR conditions used for the analysis of the GAA repeats in the first intron of the X25 gene were described by Filla et al. ${ }^{8}$, which generated PCR products of $500+3 \mathrm{n}$ base pairs (n: number of GAA triplets). These fragments were then submitted to electrophoresis in a $1 \%$ agarose gel and were separated by size. The expansions size analysis was estimated by comparison of the amplified fragment with a $1 \mathrm{~kb}$ ladder (GIBCO BRL) using the calculations described by Southern ${ }^{9}$.

\section{CASE REPORTS AND RESULTS}

\section{Typical cases}

Case 1 was a 21 year-old man, the first son of healthy ,non-consanguineous parents of German ancestry. Since his first decade of life, he showed a progressive unstable gait. On physical examination, he had limb and ocular ataxia, absence of myotatic reflexes and extensor plantar responses. Sensory and motor conduction velocities were very reduced. Brain magnetic resonance images (MRI) were normal. On electrocardiogram (EKG), there were signs of overload and left ventricular hypertrophy.

His 9 and 15 year-old sisters were asymptomatic, and DNA study was not performed.

X25 gene analysis showed 641 GAA repeats in both chromosomes.

Case 2 was a 44 year-old woman, with healthy and consanguineous (first cousins) parents. Among her 9 siblings, 3 were also affected. Unfortunately, none of the siblings could be examined. She showed gait ataxia since 18 years old, being, at the time of examination, dependent of wheelchair. On physical examination, ataxia kept her from walking or standing up; there were also limb incoordenation, absence of tendon reflexes, extensor plantar responses and loss of vibratory sense on the legs. Neurophysiological studies revealed a mixed, mainly sensitive neuropathy.She presented tricuspid insufficiency on echocardiogram, and $\mathrm{T}$ wave abnormalities on EKG.

She had 442 and 553 GAA repeats respectively in each allele of the X25 gene. 
Case 3 was a 12 year-old girl, daughter of consanguineous (first cousins) parents. Aside from ataxia, she also showed a familial brachydactyly, inherited from her father as an autosomal dominant trait. She started with frequent falls and a progressive scoliosis from the age of 4 , showing, in the following years, dysarthria and ataxic gait. On physical examination, she showed dysmetria, absence of myotatic reflexes, flexor plantar responses and vibration and position sense loss. On conduction nerve studies, there were reduction of motor and sensory velocities, and on echocardiogram there was a left ventricular hypertrophy.

Her 10 year-old sister did not have FRDA symptoms. Her DNA analysis was not performed.

The analysis of the X25 gene in this patient showed homozygosity for 955 GAA repeats.

Case 4 was a 27 year-old woman, the first daughter of healthy, non-consanguineous parents. After her birth, it was noticed that she had unilateral cleft lip. There was familial history of this anomaly: one maternal uncle and one paternal uncle also have cleft lip. She has showed progressive gait ataxia since 12 years old. In the following years, she began with dysarthria and frequent falls. On physical examination, she displayed dysarthria, appendicular ataxia, absence of myotatic reflexes, extensor plantar responses and position sense loss; ataxia kept her from walking alone. She presented mild tricuspid and mitral insufficiency on echocardiogram. Her CT scan was normal.

Her sister was 23 year-old, and did not have FRDA symptoms. Her DNA analysis was not performed.

X25 gene analysis showed heterozygosity for 759 and 875 GAA repeats (Fig 1).

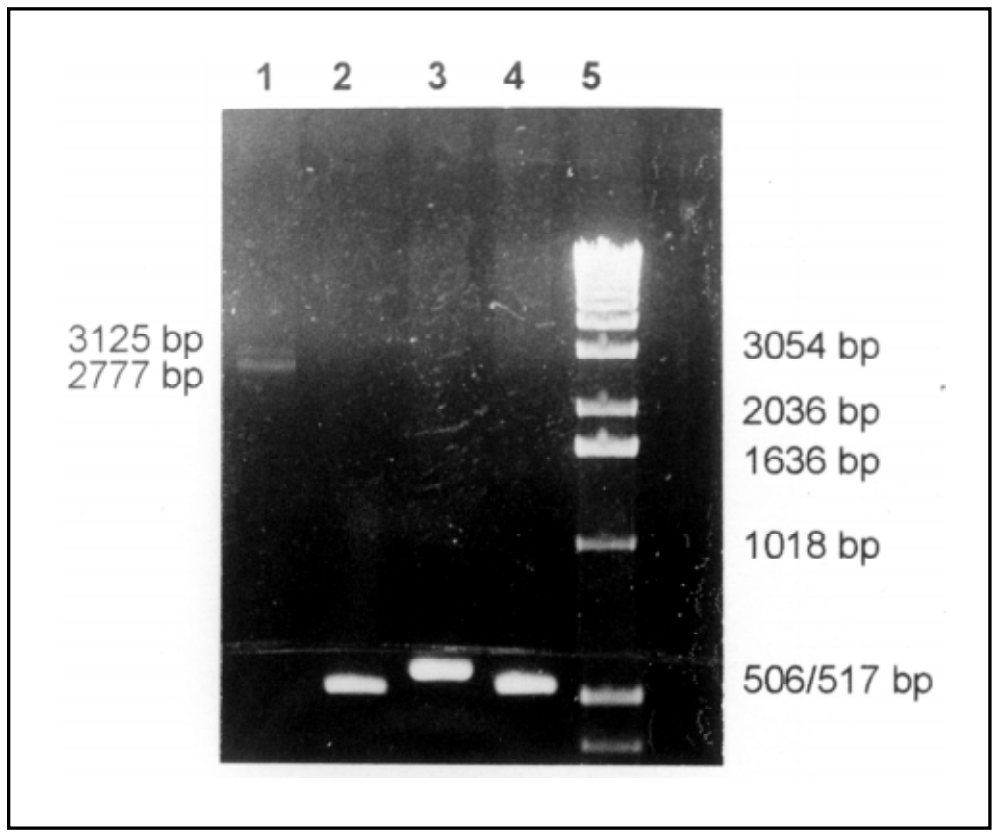

Fig 1. PCR analysis of intron 1 of the X25 gene of Case 4 and three normal controls. The PCR products were electrophoresed on a $1 \%$ agarose gel stained with ethidium bromide. Lane 1. Case 4 showing two bands with 759 e 875 repeats (2777 and 3125 bp respectively). Lanes 2 to 4 . Normal controls

Lane $5.1 \mathrm{~kb}$ DNA ladder. 


\section{Atypical case}

Case 5 was a 30 year-old man, the fifth son of healthy, non-consaguineous parents of Italian ancestry. He had two sibs also affected. His ataxia began at 25 years old. On physical examination he displayed dysarthria, truncal and apendicular ataxia, nystagmus and loss of vibratory sense on both legs. Deep-tendon reflexes were, however, preserved, and the plantar responses were flexor. There was mild cerebellar atrophy on CT scan. Cardiological evaluation was normal. The normal reflexes (including the plantar responses), the late onset of the disease and the absence of cardiac involvement were all atypical findings.

The X25 gene analysis in this patient showed 224 and 955 GAA repeats respectively for each allele.

\section{DISCUSSION}

The trinucleotide repeat expansions are now a well known mutagenic mechanism in human genetics. Friedreich ataxia, FRDA, is the first autosomal recessive disease associated to this mechanism: GAA expansion is detected in all patients, most (94\%) of them being homozygous for the mutation ${ }^{10}$. Compound heterozygotes carrying a trinucleotide expansion on one parental allele and a point mutation on the other may account for the 5-6\% of patients with FRDA ${ }^{11}$.

Besides confirming the clinical diagnosis of FRDA in four patients with typical manifestations, the molecular investigations determined the same diagnosis in an atypical patient (Case 5). This patient had a late-onset of symptoms ( 25 years of age), preserved reflexes, flexor plantar responses and normal cardiological evaluation.

As many other cases with retained reflexes and/or with late-onset were diagnosed by molecular analysis as FRDA ${ }^{10,12}$, the existence of other forms of autosomal recessive cerebellar ataxia without biological markers, such as EOCA, is doubtful. They probably represent FRDA variants with lateonset (LOFA) or with retained reflexes (FARR).

The size of GAA expansions, in our cases, were smaller than those found by Filla et al. in 67 European patients ${ }^{13}$. These authors found expanded alleles with 201-1186 GAA repeats. The mean, in that study, was of 816 repeats, with a SD of 188: our mean is 700. This probably happened because of the small size of our sample.

It is known that there is an inverse correlation between the size of the smaller expanded allele and the age of onset and severity of FRDA ${ }^{14}$. One of our five patients showed LOFA (Case 5, also being described as atypical, or as a case of FARR). This patient has the smallest expanded alelle of our sample (224 GAA repeats), which could explain the milder form of his disease.

In Cases 2 and 3, the two expanded alleles have the same origin. The parents are consanguineous (first cousins in both cases). While in Case 3 the expansion seemed to be stable (as only one PCR amplification product of GAA repeats was seen on the lane, corresponding to 955 repeats), in Case 2 the mutation proved to be unstable (442/553 repeats). Monrós et al. also observed allelic size variation in some FRDA patients expected to be homozygous by descent ${ }^{10}$. This phenomenon can be explained by meiotic instability of the GAA-trinucleotide repeat.

In Case 1, on the other hand, the two expanded alleles have not the same origin. However, we have observed only one PCR amplification product of GAA repeats on the lane, corresponding to 641 repeats. As point mutations in the gene X25 have low frequency ${ }^{13}$ and this patient has typical findings of FRDA, we believe that he has two expanded repeats of the same size (641/641).

In conclusion, we stress the significance of FRDA direct molecular diagnosis as an essential tool in clinical practice, mainly for confirming the diagnosis of atypical cases.

Acknowledgement - We greatly acknowledge Ursula da Silveira Matte who kindly set up the computer program for the analysis of the GAA repeats number. 


\section{REFERENCES}

1. Online Mendelian Inheritance in Man (OMIM). A catalogue of human genes and genetic disorders. Baltimore: The Johns Hopkins University, 1997.

2. Bidichandani SI, Ashizawa T, Patel PI. The GAA triplet-repeat expansion in Friedreich ataxia interferes with transcription and may be associated with an unusual DNA structure. Am J Hum Genet 1998;62:111-121.

3. Harding AE. Early onset cerebellar ataxia with retained tendon reflexes: a clinical and genetic study of a disorder distinct from Friedreich's ataxia. J Neurol Neurosurg Psychiatry 1981;44:503-508.

4. Campuzano V, Montermini L, Moltò MD, et al. Friedreich ataxia: autosomal recessive disease caused by na intronic GAA triplet repeat expansion. Science 1996;271:1423-1427

5. Carvajal JJ, Pook MA, Santos M, et al. The Friedreich's ataxia gene encodes a novel phosphatidylinositol-4-phosphate 5kinase. Nature Genet 1996;14:157-162.

6. Babcock M, Silva D, Oaks R, et al. Regulation of mitochondrial iron accumulation by Yfhlp, a putative homolog of frataxin. Science 1997;276:1709-1712.

7. Miller SA, Dykes DD, Polesky HF. A simple salting out procedure for extracting DNA from human nucleated cells. Nucleic Acids Res 1988;16:1215.

8. Filla A, De Michele G, Marconi R, et al. Prevalence of hereditary ataxias and spastic paraplegias in Molise, a region of Italy. J Neurol 1992;239:351-353.

9. Southern, EM. Measurement of DNA length by gel electrophoresis. Analyt Biochem 1979;100:319-323.

10. Monrós E, Molto MD, Martinez F, et al. Phenotype correlation and intergenerational dynamics of the Friedreich ataxia GAA trinuceotide repeat. Am J Hum Genet 1997;61:101-110.

11. Epplen C, Epplen JT, Frank G, Mitersi B, Santos EJM, Schöls L. Differential stability on the (GAA)n tract in the Friedreich ataxia (STM7) gene. Hum Genet 1997;99:834-836.

12. Montermini L, Richter A, Morgan K, et al. Phenotypic variability in Friedreich ataxia: role of the associated GAA triplet repeat expansion. Ann Neurol 1997;41:675-682.

13. Filla A, De Michele G, Cavalcanti F, et al. The relationship between trinucleotide (GAA) repeat length and clinical features in Friedreich ataxia. Am J Hum Genet 1996; 59:554-560.

14. Dürr A, Cossee M, Agid Y, et al. Clinical and genetic abnormalities in patients with Friedreich ataxia. N Engl J Med 1996;335:1169-1175. 